\title{
Modularity design of instant coffee powder packaging machine
}

\author{
Svetlin Antonov ${ }^{1}$, and L.K. Dien ${ }^{2, *}$ \\ ${ }^{1}$ Technical university of Sofia, Faculty of telecommunications, Bulgaria \\ ${ }^{2}$ Saigon Technology University (STU), Faculty of Mechanical Engineering, Vietnam
}

\begin{abstract}
For a long time, coffee has become a very popular drinks in over the world and Vietnam has been an coffee export country because of the quality of Vietnamese coffee is confirmed in the world. By the above reason, the question of coffee packaging for protection of its favor and transportation is considered one of the most important question. most products after the production process are fine packed in many different forms. Almost all products are especially packaged and quantified for convenient consumption depending on the form and texture of the product, there are different product packaging. Among the packaged products, instant coffee powder is the most packaged product. The coffee export market of Vietnam is very large in all around the world with the ranking of 4th. However, most instant coffee products in Vietnam are mainly invested by foreign companies with production lines system imported from foreign countries. This is the reason of the existence of the paper in which we mention on the design of a local instant coffee power with the application of the modular design.
\end{abstract}

\section{Introduction}

Modular design of mechanical products has developed rapidly in recent years [1]. By implementing the modular design, the enterprise can reduce cost and improve competitiveness largely. it is necessary to consider the modular design characteristics during the phase of product design, to facilitate product efficiency, shortening the supply cycle, improving product quality and reliability, reuse, upgrade and maintenance, and to make it easier to disassemble and recover [2, 3, 4]. At present, there is yet to be a very perfect and precise method which can solve the problems in modular design. Due to the trend of the diversification of customers' demands, small product batches with high varieties, modular design has been applied widely [5].

From the needs that are analysed above, it is necessary to modularize the design of product packaging machine. The design modular object is an instant coffee packaging machine.

\footnotetext{
* Corresponding author: dien.lekhanh@stu.edu.vn
} 


\section{Method of system design}

To functional analysis for design products [6], from the above complete general functions, we analyze the sub-functions as the diagram that shows in Fig. 1.

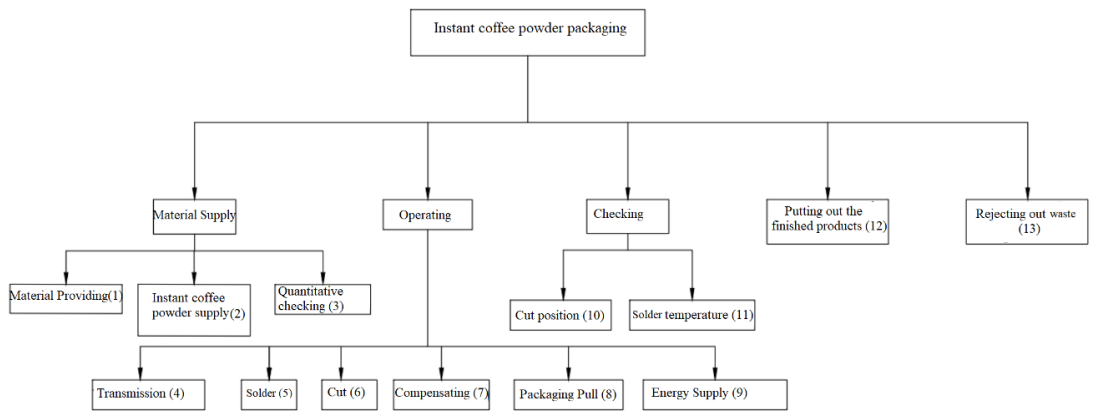

Fig. 1. Schema of sub-function of the designed product.

First step is to propose some ideas for the design problem [6]: Deploying ideas for each function, combining ideas systematically, we get 04 ideas for instant coffee packaging machine as shown in Table 1.

Table 1. Implementation ideas for each function.

\begin{tabular}{|c|c|c|c|c|}
\hline Function & Idea 1 & Idea 2 & Idea 3 & Idea 4 \\
\hline $\begin{array}{l}\text { Raw-material } \\
\text { supply }\end{array}$ & $\begin{array}{c}\text { Semi-automatic } \\
\text { raw-material } \\
\text { supply }\end{array}$ & $\begin{array}{l}\text { Frequentative } \\
\text { raw-material } \\
\text { supply by hand }\end{array}$ & $\begin{array}{l}\text { Automatic raw- } \\
\text { material supply }\end{array}$ & $\begin{array}{l}\text { Frequentative raw- } \\
\text { material supply by } \\
\text { hand }\end{array}$ \\
\hline $\begin{array}{l}\text { Quantify } \\
\text { Gauge }\end{array}$ & $\begin{array}{c}\text { Volume quantify } \\
\text { by cup }\end{array}$ & $\begin{array}{l}\text { Volume quantify } \\
\text { by rotative barrel }\end{array}$ & $\begin{array}{c}\text { Quantitative } \\
\text { feeding by } \\
\text { electrical control }\end{array}$ & $\begin{array}{c}\text { Quantitative } \\
\text { feeding by } \\
\text { continuous weight } \\
\text { feeding }\end{array}$ \\
\hline Transmission & $\begin{array}{l}\text { Mono electric } \\
\text { motor system }\end{array}$ & $\begin{array}{l}\text { Mono electric } \\
\text { motor system }\end{array}$ & $\begin{array}{c}\text { Two electric } \\
\text { motor system }\end{array}$ & $\begin{array}{l}\text { Two electric } \\
\text { motor system }\end{array}$ \\
\hline Welding & Roller system & $\begin{array}{l}\text { Pushing rod } \\
\text { system }\end{array}$ & Roller system & $\begin{array}{c}\text { Pushing rod } \\
\text { system }\end{array}$ \\
\hline Cutting & Roller system & $\begin{array}{c}\text { Pushing rod } \\
\text { system }\end{array}$ & Roller system & $\begin{array}{c}\text { Pushing rod } \\
\text { system }\end{array}$ \\
\hline $\begin{array}{c}\text { Package } \\
\text { compensating }\end{array}$ & Differentiel motor & Servo motor & $\begin{array}{l}\text { Differentiel } \\
\text { motor }\end{array}$ & Servo motor \\
\hline $\begin{array}{l}\text { Package } \\
\text { pulling }\end{array}$ & Roller system & $\begin{array}{c}\text { Roller-Pulley } \\
\text { system }\end{array}$ & Roller system & $\begin{array}{c}\text { Roller-Pulley } \\
\text { system }\end{array}$ \\
\hline $\begin{array}{l}\text { Energy } \\
\text { supply }\end{array}$ & 3-phase motor & 3-phase motor & 3-phase motor & 3-phase motor \\
\hline $\begin{array}{l}\text { Cutting } \\
\text { position }\end{array}$ & Sensor & Switch journey & Sensor & Switch journey \\
\hline $\begin{array}{c}\text { Welding } \\
\text { temperature }\end{array}$ & Solenoid-Sensor & Solenoid & Solenoid-Sensor & Heat Camera \\
\hline $\begin{array}{l}\text { Getting out } \\
\text { the finished } \\
\text { products }\end{array}$ & Receiving trough & Roller system & Receiving trough & Roller system \\
\hline $\begin{array}{l}\text { Getting out } \\
\text { the waste }\end{array}$ & Receiving trough & Roller system & Receiving trough & Roller system \\
\hline
\end{tabular}


Pre-selection evaluation of ideas for design products [6]: Ideas are listed on the first horizontal row of the selection matrix. Selection criteria are arranged along the left column of the matrix. Choosing one of the above ideas as a standard one. Analysing one in these ideas that is compared with standard one according to the selection criteria and scored in the corresponding box (Table 2). From the above ideas we see that ideas 3 and 4 are feasible when design the product.

Table 2. Matrix of evaluation the ideas.

\begin{tabular}{|l|c|c|c|c|}
\hline \multirow{2}{*}{ Creteria } & \multicolumn{4}{c|}{ Ideas } \\
\cline { 2 - 5 } & $\mathbf{1 ( S t a n d a r d )}$ & $\mathbf{2}$ & $\mathbf{3}$ & $\mathbf{4}$ \\
\hline Logical productivity & 0 & 0 & + & + \\
\hline $\begin{array}{l}\text { The quality of the } \\
\text { product respond to the } \\
\text { demands of customers }\end{array}$ & 0 & - & + & + \\
\hline $\begin{array}{l}\text { Acceptable qualitative } \\
\text { error }\end{array}$ & - & 0 & + & + \\
\hline $\begin{array}{l}\text { Easy operating, high } \\
\text { reability and longivity }\end{array}$ & 0 & 0 & + & + \\
\hline $\begin{array}{l}\text { Time of material supply } \\
\text { and change type }\end{array}$ & 0 & 0 & + & 0 \\
\hline Logical price & + & + & - & 0 \\
\hline $\begin{array}{l}\text { Environmental hygenic } \\
\text { safety }\end{array}$ & 0 & 0 & 0 & 5 \\
\hline Total score of + & 1 & 1 & 5 & 1 \\
\hline Total score of 0 & 6 & 5 & 1 & 0 \\
\hline Total score of - & 1 & 1 & 1 & 5 \\
\hline Final total score & 0 & 0 & 4 & Yes \\
\hline Ranking & 4 & 3 & 2 & Yes \\
\hline Continue? & No & No & & \\
\hline
\end{tabular}

Scoring for the final product design [6]: Decision matrix with additional weight column. Selection criteria are assigned a weight (in \% value) which are determined by agreement of the design team. Analysing each idea that is compared with the standard one according to the selected criteria and scored in the corresponding box. Calculating the total score of each idea by the formula:

$$
S_{j}=\sum_{i=1}^{n} r_{i j} w_{i}
$$

where: $r_{i j}$ - the first criterion point of idea $\mathrm{j} ; w_{i}$-the weight of the $\mathrm{i}^{\text {-th }}$ criterion; $n$-total number of criteria; $S_{j}$ - total score for idea $j$.

Ranking the ideas by total score is showed in Table 3.

Table 3. Matrix of scoring and selection of ideas.

\begin{tabular}{|l|c|c|c|c|c|}
\hline \multirow{2}{*}{ Criteria } & \multirow{2}{*}{$\begin{array}{c}\text { Weight } \\
\text { (\%) }\end{array}$} & \multicolumn{3}{|c|}{3} & \multicolumn{2}{|c|}{ Idea } \\
\cline { 3 - 6 } & & \multicolumn{2}{|c|}{ Score } & \multicolumn{2}{|c|}{ Score } \\
\cline { 3 - 6 } & & Coarse & $\begin{array}{c}\text { Multiplied } \\
\text { to weight }\end{array}$ & Coarse & $\begin{array}{c}\text { Multiplied to } \\
\text { weight }\end{array}$ \\
\hline Reasonable productivity & 20 & 4 & 0,8 & 4 & 0,8 \\
\hline The quality of the & 20 & 4 & 0,8 & 5 & 1 \\
\hline
\end{tabular}




\begin{tabular}{|c|c|c|c|c|c|}
\hline $\begin{array}{l}\text { product respond to the } \\
\text { demands of customers }\end{array}$ & & & & & \\
\hline $\begin{array}{l}\text { Acceptable qualitative } \\
\text { error }\end{array}$ & 10 & 4 & 0,4 & 4 & 0,4 \\
\hline $\begin{array}{l}\text { Easy operating, high } \\
\text { reability and longivity }\end{array}$ & 10 & 3 & 0,3 & 3 & 0,3 \\
\hline $\begin{array}{l}\text { Time of material supply } \\
\text { and change type }\end{array}$ & 10 & 3 & 0,3 & 3 & 0,3 \\
\hline Logical price & 20 & 2 & 0,2 & 4 & 0,8 \\
\hline $\begin{array}{l}\text { Environmental hygenic } \\
\text { safety }\end{array}$ & 10 & \multicolumn{2}{|c|}{3} & \multicolumn{2}{|c|}{0,3} \\
\hline Total score & 100 & \multicolumn{2}{|c|}{3.1} & \multicolumn{2}{|c|}{399} \\
\hline ranking & 1 & \multicolumn{2}{|c|}{2} & & \\
\hline Continue? & & & & \multicolumn{2}{|c|}{ Yes } \\
\hline
\end{tabular}

Based on the scoring matrix, we selected an idea as a design concept. The principle diagram is displayed in figure 2.

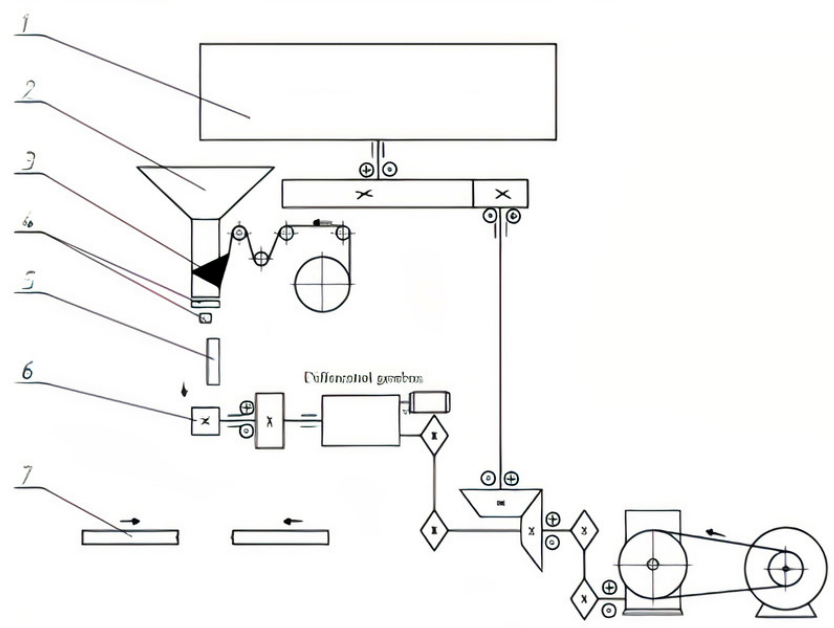

Fig. 2. Schema of theory of packaging machine.

Description of the system:

The motor drives the packaging pull assembly, the roll bag is fed to the shaft with the two end stoppers at its 2 ends (2), the bag head is pulled out through the guide rollers cluster (3) by the pull assembly rollers (5) and shaped by forming module (4) and at the same time it is welded by the vertical packaging module (6), then horizontally welded and packaging cut in the cluster (7). In the mean-while the motor also drives the metering assembly (1) to rotate the wheel quantifies through the measuring cups and down to the lower packaging through the hole that was created at product shaping assembly. The quantified material in the metering module falls into the shaped horizontal weld edge and a vertical weld edge packaging. Then the vertical welding module and the packaging cutting (7) welds the horizontal line and cut the packaging and finish the product (8). In case when the pull-out package is not long enough, the auxiliary engine will turn to the differential gearbox and pull out the packaging so that it can pack accurately according to the given data. 


\section{Results and discussion}

After analysing customers' demands and choosing design ideas for the product [7] the next step is applying the design product modularization method to design the product system. Finally the combination of functional analysis diagrams and design concepts in one structural - functional power diagram is illustrated as follows:

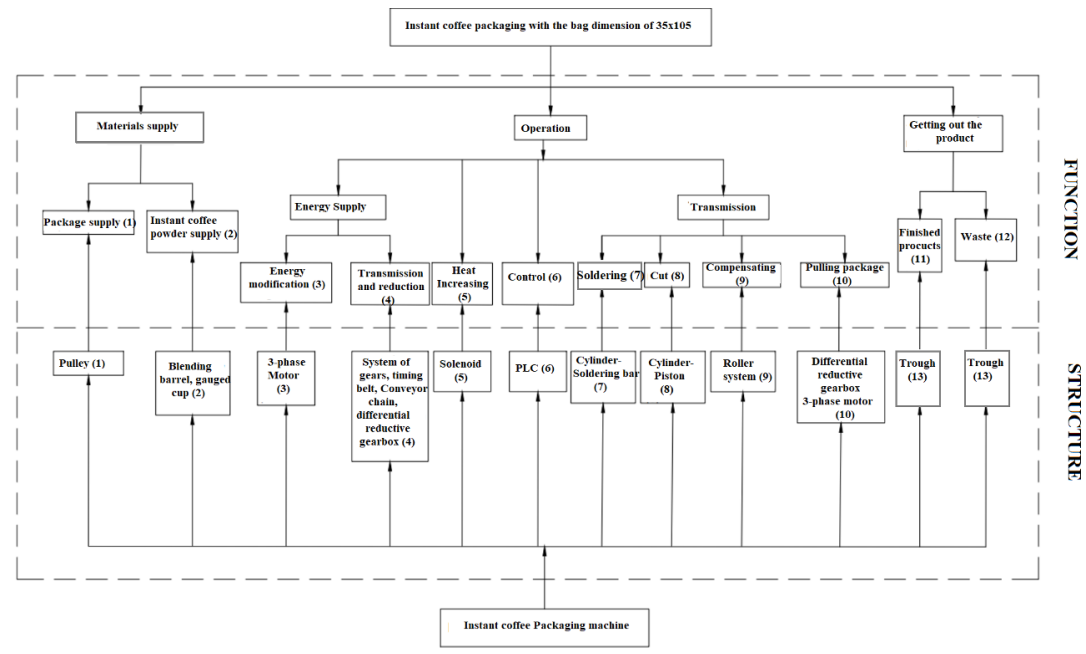

Fig. 3. Schema of structure and function.

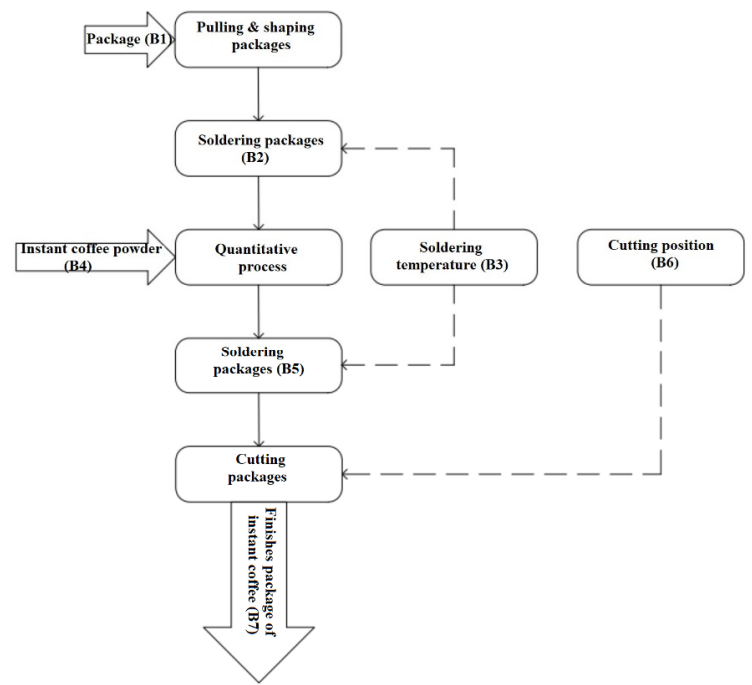

Fig. 4. Schema of process of general function of Instant Coffee Packaging Machine. 
The main function of the machine is: raw materials supplying (instant coffee, packaging) and packaging into bags. The sub-functions are: providing the package in, shaping, soldering packages, pulling out and cutting packages.

List of the components and designation is shown in Table 4:

Table 4. Designation of components in instant powder coffee machine.

\begin{tabular}{|c|l|c|}
\hline No & \multicolumn{1}{|c|}{ Components } & Designation \\
\hline 1 & Main 3-phase motor & DCC \\
\hline 2 & 3-phase motor gearbox & DCP \\
\hline 3 & Reductive Gearbox & HGT \\
\hline 4 & Chain transmission & BTX \\
\hline 5 & Taper gear transmission & BRC \\
\hline 6 & Spur gear transmission & BRT \\
\hline 7 & Hopper & PTB \\
\hline 8 & Roller for rolling package & CLK \\
\hline 9 & Soldering bar & THX \\
\hline 10 & Cutting bar & TKX \\
\hline 11 & Quantitative cup & CDL \\
\hline
\end{tabular}

The system-level specifications of the products are arranged in a hierarchical structure [7] in which the physical structure is divided by the arrangement and the interactive state (direct, indirect), while the functional structure is divided by the flow of energy, materials and information (Figure 5).

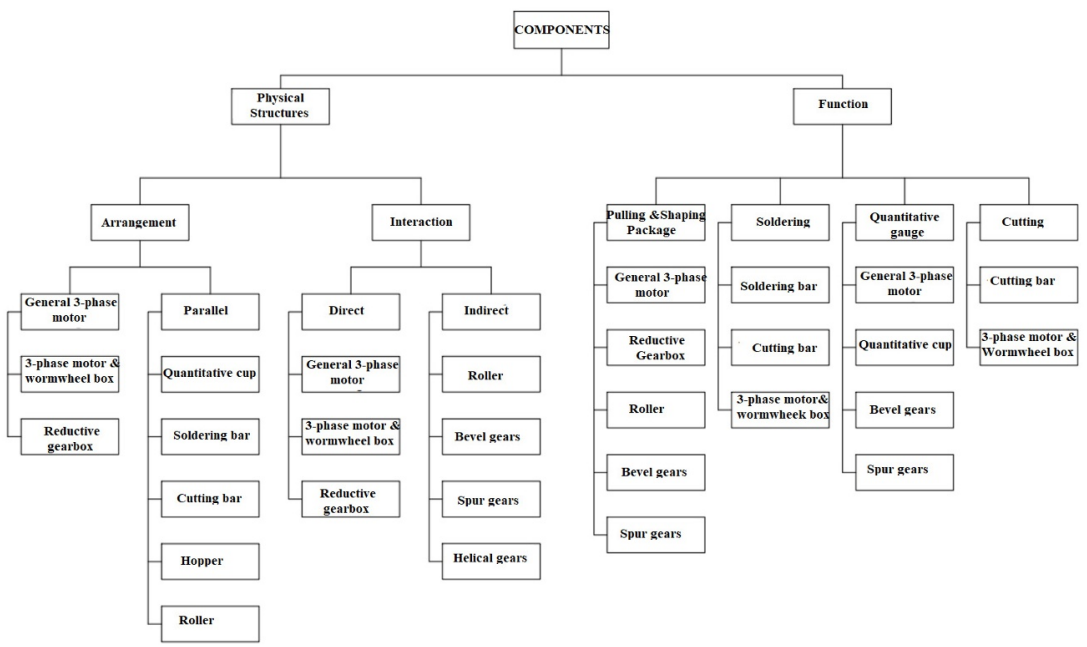

Fig. 5. Schema of the relation among details and modules in the designed machine.

Establishing the relationships among the details in a system [7] through system properties of physical structure and function (Table 5), number 1 represents interaction, 0 represents no relationship system. 
Table 5. The relation among details and modules in the designed machine.

\begin{tabular}{|c|c|c|c|c|c|c|c|c|c|}
\hline \multirow{3}{*}{\multicolumn{2}{|c|}{$\begin{array}{c}\text { Detail/ } \\
\text { module }\end{array}$}} & \multicolumn{4}{|c|}{ Structure } & \multicolumn{4}{|c|}{ Function } \\
\hline & & \multicolumn{2}{|c|}{ Arrangement } & \multicolumn{2}{|c|}{ Position } & \multirow{2}{*}{ KD } & \multirow{2}{*}{ HB } & \multirow{2}{*}{ DL } & \multirow{2}{*}{ CB } \\
\hline & & NT & SS & TT & TR & & & & \\
\hline \multirow{10}{*}{$\begin{array}{l}\text { D } \\
\text { C } \\
\text { C }\end{array}$} & $D C P$ & 1 & 0 & 1 & 0 & 1 & 0 & 1 & 0 \\
\hline & $H G T$ & 1 & 0 & 1 & 0 & 1 & 0 & 0 & 0 \\
\hline & $B T X$ & 0 & 0 & 1 & 1 & 1 & 0 & 0 & 0 \\
\hline & $B R C$ & 0 & 0 & 0 & 1 & 1 & 0 & 1 & 0 \\
\hline & $B R T$ & 0 & 0 & 0 & 1 & 1 & 0 & 1 & 0 \\
\hline & $P T B$ & 0 & 0 & 0 & 0 & 0 & 0 & 1 & 0 \\
\hline & $C L K$ & 0 & 0 & 1 & 0 & 1 & 0 & 0 & 0 \\
\hline & $T H X$ & 0 & 0 & 0 & 0 & 0 & 1 & 0 & 0 \\
\hline & $T K X$ & 0 & 0 & 0 & 0 & 0 & 0 & 0 & 1 \\
\hline & $C D L$ & 0 & 0 & 0 & 0 & 0 & 0 & 1 & 0 \\
\hline \multirow{9}{*}{$\begin{array}{l}\text { D } \\
\text { C } \\
\text { P }\end{array}$} & HGT & 1 & 0 & 1 & 0 & 1 & 0 & 0 & 0 \\
\hline & BTX & 0 & 0 & 1 & 1 & 1 & 0 & 0 & 0 \\
\hline & $\mathrm{BRC}$ & 0 & 0 & 1 & 0 & 1 & 0 & 1 & 0 \\
\hline & BRT & 0 & 0 & 0 & 1 & 1 & 0 & 1 & 0 \\
\hline & PTB & 0 & 0 & 0 & 0 & 0 & 0 & 1 & 0 \\
\hline & CLK & 0 & 0 & 1 & 0 & 1 & 0 & 0 & 0 \\
\hline & THX & 0 & 0 & 0 & 0 & 0 & 1 & 0 & 0 \\
\hline & TKX & 0 & 0 & 0 & 0 & 0 & 0 & 0 & 1 \\
\hline & $\mathrm{CDL}$ & 0 & 0 & 0 & 0 & 0 & 0 & 1 & 0 \\
\hline \multirow{8}{*}{$\begin{array}{c}\mathbf{H} \\
\mathbf{G} \\
\mathbf{T}\end{array}$} & BTX & 0 & 0 & 1 & 1 & 1 & 0 & 0 & 0 \\
\hline & BRC & 0 & 0 & 1 & 0 & 1 & 0 & 1 & 0 \\
\hline & BRT & 0 & 0 & 0 & 1 & 1 & 0 & 1 & 0 \\
\hline & PTB & 0 & 0 & 0 & 0 & 0 & 0 & 1 & 0 \\
\hline & CLK & 0 & 0 & 1 & 0 & 1 & 0 & 0 & 0 \\
\hline & THX & 0 & 0 & 0 & 0 & 0 & 1 & 0 & 0 \\
\hline & TKX & 0 & 0 & 0 & 0 & 0 & 0 & 0 & 1 \\
\hline & CDL & 0 & 0 & 0 & 0 & 0 & 0 & 1 & 0 \\
\hline \multirow{7}{*}{$\begin{array}{l}\mathbf{B} \\
\mathbf{T} \\
\mathbf{X}\end{array}$} & BRC & 0 & 0 & 1 & 0 & 1 & 0 & 1 & 0 \\
\hline & BRT & 0 & 0 & 0 & 1 & 1 & 0 & 1 & 0 \\
\hline & PTB & 0 & 0 & 0 & 0 & 0 & 0 & 1 & 0 \\
\hline & CLK & 0 & 0 & 1 & 0 & 1 & 0 & 0 & 0 \\
\hline & THX & 0 & 0 & 0 & 0 & 0 & 1 & 0 & 0 \\
\hline & TKX & 0 & 0 & 0 & 0 & 0 & 0 & 0 & 1 \\
\hline & CDL & 0 & 0 & 0 & 0 & 0 & 0 & 1 & 0 \\
\hline \multirow{6}{*}{$\begin{array}{l}\text { B } \\
\mathbf{R} \\
\mathbf{C}\end{array}$} & BRT & 0 & 0 & 0 & 1 & 1 & 0 & 1 & 0 \\
\hline & PTB & 0 & 0 & 0 & 0 & 0 & 0 & 1 & 0 \\
\hline & CLK & 0 & 0 & 1 & 0 & 1 & 0 & 0 & 0 \\
\hline & THX & 0 & 0 & 0 & 0 & 0 & 1 & 0 & 0 \\
\hline & TKX & 0 & 0 & 0 & 0 & 0 & 0 & 0 & 1 \\
\hline & $\mathrm{CDL}$ & 0 & 0 & 0 & 0 & 0 & 0 & 1 & 0 \\
\hline \multirow{5}{*}{$\begin{array}{l}\mathbf{B} \\
\mathbf{R} \\
\mathbf{T}\end{array}$} & PTB & 0 & 0 & 0 & 0 & 0 & 0 & 1 & 0 \\
\hline & CLK & 0 & 0 & 1 & 0 & 1 & 0 & 0 & 0 \\
\hline & THX & 0 & 0 & 0 & 0 & 0 & 1 & 0 & 0 \\
\hline & TKX & 0 & 0 & 0 & 0 & 0 & 0 & 0 & 1 \\
\hline & $\mathrm{CDL}$ & 0 & 0 & 0 & 0 & 0 & 0 & 1 & 0 \\
\hline \multirow{4}{*}{$\begin{array}{l}\mathbf{P} \\
\mathbf{T} \\
\mathbf{B}\end{array}$} & CLK & 0 & 0 & 1 & 0 & 1 & 0 & 0 & 0 \\
\hline & THX & 0 & 0 & 0 & 0 & 0 & 1 & 0 & 0 \\
\hline & TKX & 0 & 0 & 0 & 0 & 0 & 0 & 0 & 1 \\
\hline & $\mathrm{CDL}$ & 0 & 0 & 0 & 0 & 0 & 0 & 1 & 0 \\
\hline
\end{tabular}




\begin{tabular}{|c|c|c|c|c|c|c|c|c|c|}
\hline $\mathbf{C}$ & THX & 0 & 0 & 0 & 0 & 0 & 1 & 0 & 0 \\
\cline { 2 - 10 } $\mathbf{L}$ & TKX & 0 & 0 & 0 & 0 & 0 & 0 & 0 & 1 \\
\cline { 2 - 10 } $\mathbf{K}$ & CDL & 0 & 0 & 0 & 0 & 0 & 0 & 1 & 0 \\
\hline $\mathbf{T}$ & TKX & 0 & 0 & 0 & 0 & 0 & 0 & 0 & 1 \\
\cline { 2 - 9 } $\mathbf{H}$ & CDL & 0 & 0 & 0 & 0 & 0 & 0 & 1 & 0 \\
\hline $\mathbf{T}$ & & & 0 & 0 & 0 & 0 & 0 & 1 & 0 \\
$\mathbf{K}$ & $\mathrm{CDL}$ & 0 & 0 & & & & & & \\
$\mathbf{X}$ & & & & & & & & &
\end{tabular}

Where: NT - Serial; SS - Parallel; TT - Direct interactive; TR - Separate; KD - Pulling package in and forming; HB - Soldering packages; DL - Quantitative gauge, CB - Cutting packages.

Determining the degree of influence of System - Level Specification (SLS) on General Functional Requirements (GFR) [7]: To determine the effect of the designed machine performance on functional requirements, a relationship matrix between System - Level Specification (SLS) on General Functional Requirements (GFR):

$\checkmark \quad$ The desired impact value is 1 ;

$\checkmark \quad$ The value 0 stands for insignificant impact;

$\checkmark \quad$ The value -1stands for the undesirable effect.

From the above ideas we could build a matrix of relationships between machine structure and importance factors (Table 6).

Table 6. Matrix of Relation between SLS and GFR.

\begin{tabular}{|l|c|c|c|}
\hline System-Level Specification (SLS) & Ease of Service & Compactness & Performance \\
\hline Serial & 0 & 1 & 1 \\
\hline parallel & 0 & 1 & 1 \\
\hline Contact each other & 1 & 1 & 0 \\
\hline Separate each other & 0 & -1 & 1 \\
\hline Direct energy transferring & 1 & 0 & 0 \\
\hline Indirect energy transferring & 0 & 0 & 0 \\
\hline Reductive gearbox & 0 & 0 & 0 \\
\hline Non-reductive gearbox & 1 & 0 & 0 \\
\hline Weight & 1 & 1 & 1 \\
\hline
\end{tabular}

After applying the Cluster Identification Algorithm (CIA) [7], we determine the matrix of functional, structural and overall similarity:

Table 7. The structural similarity matrix.

\begin{tabular}{|l|l|l|l|l|l|l|l|l|l|l|l|}
\hline & DCC & DCP & HGT & BTX & BRC & BRT & PTB & CLK & THX & TKX & CDL \\
\hline DCC & & 4 & 4 & 2 & 2 & 0 & 0 & 0 & 0 & 0 & 0 \\
\hline DCP & 4 & & 4 & 2 & 2 & 0 & 0 & 0 & 0 & 0 & 0 \\
\hline HGT & 4 & 4 & & 2 & 2 & 0 & 0 & 0 & 0 & 0 & 0 \\
\hline BTX & 2 & 2 & 2 & & 0 & 0 & 0 & 0 & 0 & 0 & 0 \\
\hline BRC & 2 & 2 & 2 & 0 & & 2 & 1 & 0 & 0 & 0 & 0 \\
\hline RT & 0 & 0 & 0 & 0 & 2 & & 2 & 0 & 0 & 0 & 0 \\
\hline PTB & 0 & 0 & 0 & 0 & 1 & 2 & & 1 & 0 & 0 & 0 \\
\hline CLK & 0 & 0 & 0 & 0 & 0 & 0 & 1 & & 1 & 0 & 0 \\
\hline THX & 0 & 0 & 0 & 0 & 0 & 0 & 0 & 1 & & 0 & 0 \\
\hline TKX & 0 & 0 & 0 & 0 & 0 & 0 & 0 & 0 & 0 & & 2 \\
\hline CDL & 0 & 0 & 0 & 0 & 0 & 0 & 0 & 0 & 0 & 2 & \\
\hline
\end{tabular}


Table 8. The functional similarity matrix.

\begin{tabular}{|l|l|l|l|l|l|l|l|l|l|l|l|}
\hline & DCC & DCP & HGT & BTX & BRC & BRT & PTB & CLK & THX & TKX & CDL \\
\hline DCC & & 1 & 1 & 0 & 1 & 0 & 0 & 0 & 0 & 0 & 0 \\
\hline DCP & 1 & & 1 & 1 & 0 & 0 & 0 & 0 & 0 & 0 & 0 \\
\hline HGT & 1 & 1 & & 1 & 1 & 0 & 0 & 0 & 0 & 0 & 0 \\
\hline BTX & 0 & 1 & 1 & \multicolumn{1}{l}{$\mid$} & 1 & 0 & 0 & 0 & 0 & 0 & 0 \\
\hline BRC & 1 & 0 & 1 & 1 & & 1 & 0 & 0 & 0 & 0 & 0 \\
\hline RT & 0 & 0 & 0 & 0 & 1 & & 1 & 0 & 0 & 0 & 0 \\
\hline PTB & 0 & 0 & 0 & 0 & 0 & 1 & & 1 & 0 & 0 & 0 \\
\hline CLK & 0 & 0 & 0 & 0 & 0 & 0 & 1 & & 1 & 0 & 0 \\
\hline THX & 0 & 0 & 0 & 0 & 0 & 0 & 0 & 1 & & 0 & 0 \\
\hline TKX & 0 & 0 & 0 & 0 & 0 & 0 & 0 & 0 & 0 & & 1 \\
\hline CDL & 0 & 0 & 0 & 0 & 0 & 0 & 0 & 0 & 0 & 1 & \\
\hline
\end{tabular}

Table 9. The general similarity matrix.

\begin{tabular}{|l|l|l|l|l|l|l|l|l|l|l|l|}
\hline & DCC & DCP & HGT & BTX & BRC & BRT & PTB & CLK & THX & TKX & CDL \\
\hline DCC & & 5 & 5 & 2 & 3 & 0 & 0 & 0 & 0 & 0 & 0 \\
\hline DCP & 5 & & 5 & 3 & 2 & 0 & 0 & 0 & 0 & 0 & 0 \\
\hline HGT & 5 & 5 & & 5 & 3 & 2 & 0 & 0 & 0 & 0 & 0 \\
\hline BTX & 2 & 3 & 3 & & 1 & 0 & 0 & 0 & 0 & 0 & 0 \\
\hline BRC & 3 & 2 & 3 & 1 & & 3 & 0 & 0 & 0 & 0 & 0 \\
\hline RT & 0 & 0 & 0 & 0 & 3 & & 3 & 0 & 0 & 0 & 0 \\
\hline PTB & 0 & 0 & 0 & 0 & 0 & 3 & & 2 & 0 & 0 & 0 \\
\hline CLK & 0 & 0 & 0 & 0 & 0 & 0 & 2 & & 3 & 0 & 0 \\
\hline THX & 0 & 0 & 0 & 0 & 0 & 0 & 0 & 3 & & 0 & 0 \\
\hline TKX & 0 & 0 & 0 & 0 & 0 & 0 & 0 & 0 & 0 & & 3 \\
\hline CDL & 0 & 0 & 0 & 0 & 0 & 0 & 0 & 0 & 0 & 3 & \\
\hline
\end{tabular}

All the mechanical details of the designed machine are listed in the table below with the majority of standardized details available for easy purchase:

Table 10. Standardized details available for easy purchase.

\begin{tabular}{|c|c|c|}
\hline Mechanical details & Design for selection & $\begin{array}{c}\text { Design for } \\
\text { manufactering }\end{array}$ \\
\hline 3-phase motor & $\bullet$ & \\
\hline Cylinder & $\bullet$ & \\
\hline Roller bearings & $\cdot$ & \\
\hline Position sensors & $\bullet$ & \\
\hline Solenoids & $\bullet$ & \\
\hline Chain transmission & $\bullet$ & \\
\hline Belt transmission & $\bullet$ & \\
\hline Gearbox & $\cdot$ & \\
\hline Differential gearbox & $\cdot$ & \\
\hline Spur gear transmission & $\bullet$ & \\
\hline Bevel gear transmission & $\bullet$ & \\
\hline PLC & $\cdot$ & \\
\hline Flow control valve & $\cdot$ & \\
\hline Pneumatic system & $\bullet$ & \\
\hline Roller & & $\cdot$ \\
\hline Quantitative cup & & $\cdot$ \\
\hline Hopper & & $\cdot$ \\
\hline Keys & & - \\
\hline Machine frame & & $\bullet$ \\
\hline Machine chariot & & $\cdot$ \\
\hline Shafts & & $\cdot$ \\
\hline Driver & - & \\
\hline
\end{tabular}




\section{Conclusion}

The results of the paper illustrate that with the helping of modularity design method, the designer could perform his complicated works of design a machine that is efficiency respond all the technical demands, product quality and reliability, easy maintenance and logical price that could have a great competition. With the modular design, most of the clusters are designed for selection (purchasing from market), only seven parts are designed for manufacturing by our-self.

\section{References}

1. Báo cáo thị trường cà phê năm 2020, https://cdn.vietnambiz.vn/171464876016439296/ 2021/1/20/a2012020-bao-cao-ca-phe-nam-2020-final-16111582854511351635957.pdf. (2021).

2. PengjiaWanga, Yongxian Liua, S.K. Ongb, A.Y.C. Neeb, Modular Design of Machine Tools to Facilitate Design for Disassembly and Remanufacturing, 21st CIRP Conference on Life Cycle Engineering, Elsevier B.V (2014).

3. Qiuxiao Yang a, Kaibao Wang b, Mingzhu Zhang c, Li Zhao d, Su Hang and Ming Meng, The Design and Research on Automatic Packaging Machine of the Strains, International Conference on Management Science and Innovative Education (MSIE 2015), Atlantis Press (2015).

4. Zhihui Liu; Mengqi Li; Zhigang Chen; Zhiwei Lin; Xuemin Liu, The automatic packaging machine design based on reconfigurable theory, 2011 International Conference on Consumer Electronics, Communications and Networks (CECNet) (2011).

5. Rui Shang, Sheng Yuan Li, The Study on CAD Technology of Reconfigurable and Module for Vertical Bag Packaging Machine, Advanced Materials Research (2011).

6. Nguyễn Thanh Nam, Giáo trình phưong pháp thiết kế kỹ thuật, Nhà xuất bản đại học quốc gia Tp. Hồ Chí Minh (2014).

7. A. K. Kamrani, S. M. Salhied, Product design for modularity, Second edition (2002). 